\title{
Prevalence and Major Pathogens Associated with Clinical and Subclinical Mastitis in Dairy Camel (Camelus dromedarius) in Benadir Region of Somalia
}

\section{Abdiaziz Idiris Mohamud ${ }^{1}$, Yonis Abukar Mohamed ${ }^{2}$, Osman Sheikh Ali Jama ${ }^{3}$, Pravin Mishra ${ }^{4 *}$ and Mohamed Idiris Mohamed ${ }^{5}$}

${ }^{1}$ Department of Medicine, Faculty of Veterinary Science, Bangladesh Agricultural University, Mymensingh, Bangladesh; ${ }^{2}$ Department of Pathology and Parasitology, Faculty of Veterinary and Animal Science, Hajee Mohammad Danesh Science and Technology University, Dinajpur, Bangladesh; ${ }^{3}$ Department of Public Health, Pharmacology and Toxicology, Faculty of Veterinary Medicine, University of Nairobi, Nairobi, Kenya; ${ }^{4}$ Faculty of Veterinary Science, Bangladesh Agricultural University, Mymensingh-2202, Bangladesh; ${ }^{5}$ Faculty of Veterinary Medicine and Animal Husbandry, Somali National University, Mogadishu, Somalia.

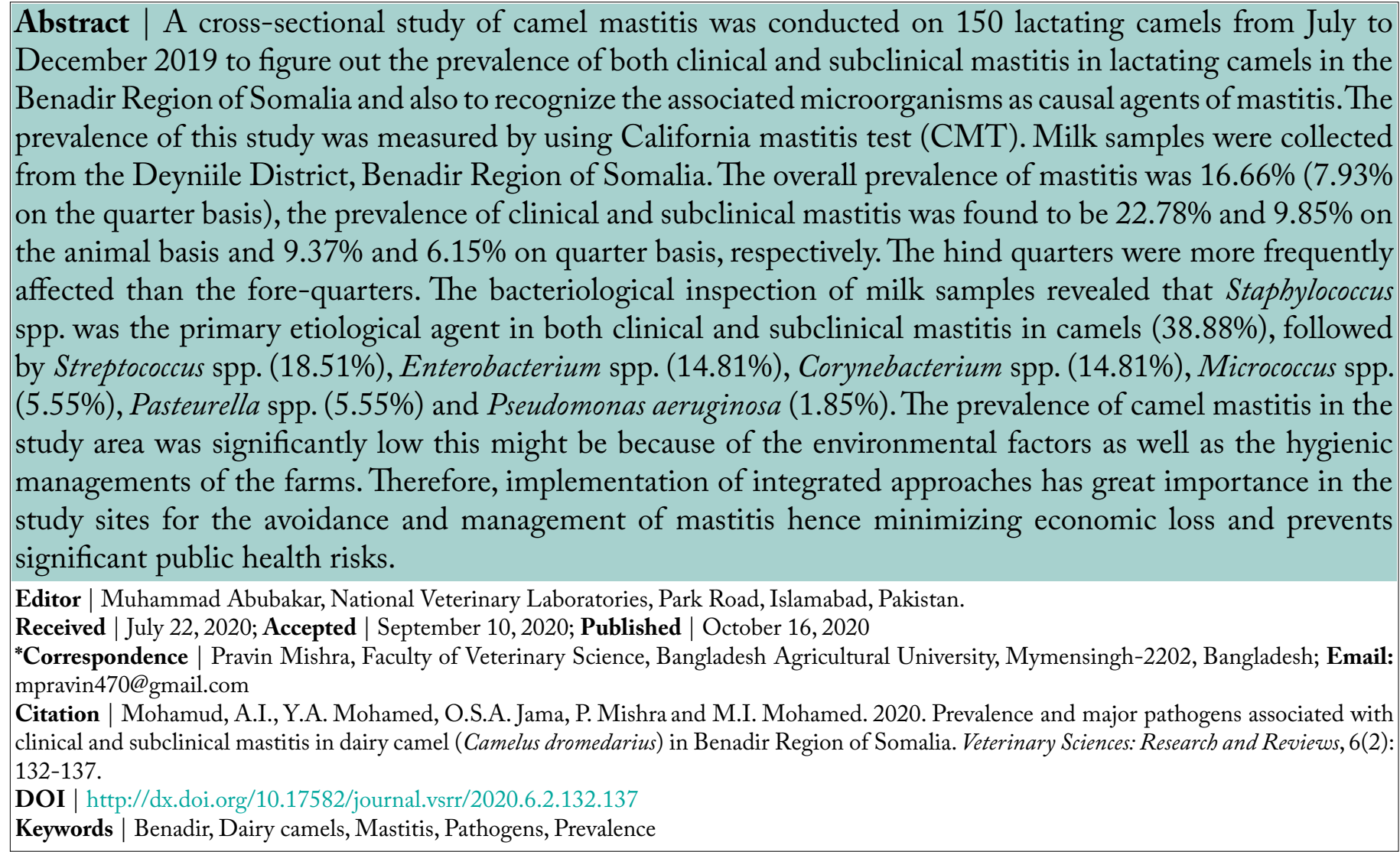

\section{Introduction}

$\mathrm{C}$ amels are important livelihood assets to human survival in less agroecological parts of African, Asian and Arabian deserts (Ali et al., 2019). According to FAO (2020), the total of camel populations of the Universe is supposed to be 35 Million, Camelus dromedarius (One Humped 
Camel) is $89 \%$ while Camelus bactrain (Two Humped camels) is only $11 \%$ and mostly kept by nomads mainly in Asia and Africa. Dromedarius camel is an important source of milk, meat and even in transportation mainly in the desert area. In addition, the camel can carry heavy loads for several days in some of the world's most hostile conditions (Köhler-Rollefson et al., 2001). Livestock rearing mainly camel is very common in Somalia's rural areas and the adjacent regions of Ethiopia, Kenya, and Djibouti. The Livestock sector is the backbone of the Somali economy since it creates employment opportunities (60\%), an income of foreign currency (80\%), as well as contributes to Gross Domestic Products (40\%) (Somalia Economy, 2020). Of the world's estimated 14 million camels, the Somalia population estimates around 10 million people and has more than seven million camels the highest number of the world (Mohamed, 2016). There is no other community in the earth like the Somali community where the camel plays such an essential part in their culture as well as in their indigenous budget (Farah et al., 2004). Although Somalia has a major population of camels in the globe, camel production is very low in terms of milk due to diseases such as mastitis. Mastitis is an inflammation of mammary glands (Mpatswenumugabo et al., 2017) and is divided into clinical mastitis which shows clinical signs and subclinical mastitis which doesn't show any clinical signs from the udder except for using detection tools. It's very easy to detect clinical mastitis by seeing clotted milk, while subclinical mastitis can be confirmed only by using several tests such as California mastitis test (CMT), Microscopic Somatic Cell Count (MSCC), Whiteside test (WST), sodium lauryl sulfate test (SLST), surf field mastitis test (SFMT) (Hoque et al., 2015; Sharma et al., 2010) and Electrical Conductivity (EC) (Hegde et al., 2013). The mastitis control program can reduce economical loss and increase herd efficacy and milk hygiene.

\section{Materials and Methods}

\section{Study animal, population and location}

A total of 150 lactating cow-camels that were kept under traditional management in the Deyniile district of the Benadir region, Somalia (Latitude: $2.073453^{\circ}$, Longitude: $45.275559^{\circ}$ ) was considered to figure out the prevalence of clinical and subclinical mastitis. The study area is close to the equator and has comparatively a dry climate. The area covers a total landmass of $1657 \mathrm{~km}^{2}$ and has a human population of 2.5 million.

\section{Study design and sampling}

The cross-sectional study was conducted from July to December 2019 on 150 lactating cow-camels in which case study animals were visited once for data collection and regarding the sampling procedure area, Deyniile District of Benadir region was selected based on present camels' population and accessibility of information thereby, accordingly collecting the sample were achieved.

\section{Sample size}

Using the method given by Thrusfield (2005) with a $95 \%$ confidence interval $(\mathrm{CI})$ and $5 \%$ desired absolute precision, the desired sample size for the study was calculated. Accordingly, the estimated sample size was 150 lactating camels.

\section{Physical examination of camel's teats and udder}

Visual inspection and systemic palpation of teats and udder of the lactating camels were done. Visible lesions of udder were recorded. The lesions included chapped cracked skin, injuries, vesicles, wounds, scars, fly bites, allergic reactions, warts, photosensitization, chemical damage, cuts, and abrasions.

\section{Collection of milk samples}

The camels were restrained and the udder washed with clean water. The teats were dried with a disposable paper towel and disinfected with $70 \%$ alcohol. Milk samples were collected from each teat of all the 150 lactating camels using aseptic methods, regardless of whether they have clinical mastitis or not. After discarding the first strips of milk, $10 \mathrm{ml}$ from each halve collected into labeled sterile sample bottles. The bottles were capped and kept in cool boxes with ice packs at $4^{\circ} \mathrm{C}$ and transported within 2 hours to the Kasmo University, Mogadishu, Somalia for laboratory analysis.

\section{Laboratory analysis of milk samples}

The CMT was done to detect mastitis in camel (clinical and subclinical). According to Quinn et al. (1999) interpretations were done and the results were scored as 0 , Trace $(\mathrm{T}), 1,2$, or 3 subjects on the concentration of reaction. Sample with a CMT score of 0 or $\mathrm{T}$ was considered as negative while those scores of 1,2 , or 3 were considered as positive. 


\section{Biological isolation}

The collected samples were cultured on the media (general, choosy and exceptional indicator media) with exceptional supplements depending on the nature of bacteria; whether they are fast/ slow developing or demanding/normal during development (i.e., aerobic, 10\% Co2 and anaerobic conditions). Depending on the species of microorganisms, the time of incubation was set from 24 to 72 hours. Temperature of incubation was $37^{\circ} \mathrm{C}$ for most of the cases although some cases need to be incubated on another range i.e. $25-45^{\circ} \mathrm{C}$. Identification of the microorganism was done by commercially presented groups of Biochemical and enzymatic analysis (API 20 A, NE, E and API 20 Coryn) fast microbial recognition systems Vitek 2 (Biomerioux France).

\section{Statistical analysis}

Collected data were organized in Microsoft Excel before transferred to the SPSS sheet. The Statistical Package for the Social Science 20.0 was used for all suitable statistical analysis.

\section{Results and Discussion}

\section{Prevalence}

A total of 150 lactating camels (580 quarters) were examined to determine the prevalence of clinical and subclinical mastitis in camels. Among 150, 79 camels (320 quarters) examined for the presence of clinical mastitis, and 18 camels (30 quarters) were positive to clinical mastitis, and the prevalence is $22.78 \%$ (9.37\% on the quarter basis). Remaining 71 camels (260 quarters) were examined for estimating the presence of subclinical mastitis, and 7 camels (16 quarters) were positive to subclinical mastitis, and the prevalence is $9.85 \%(6.15 \%$ on the quarter basis) (Table 1$)$. Mastitis pathogens were found in the udder discharge of camels confirming subclinical mastitis. Taking into consideration of total population $(n=150)$ during the study, the prevalence of mastitis on the animal basis was found to be $16.66 \%$ while $7.93 \%$ on the quarter basis. It was further observed that hind quarters were affected with both clinical and subclinical infections (69.99\% and 62.5\%, respectively) more frequently than fore-quarters $(30.00 \%$ and $37.5 \%$, respectively) (Table 2).

\section{Frequency distribution of mastitis pathogens}

The data presented on the relative frequency of types of microorganisms that come across in udder infection were mentioned in Table 3. The study showed that Staphylococcus spp. was the greatest significant organism involved in the causation of clinical and subclinical mastitis in camels (38.88\%) followed by Streptococcus spp. (18.51\%) and become the second most pathogen involved as a causative agent, Enterobacterium spp. and Corynebacterium spp. (14.81\%). The prevalence of miscellaneous organisms including Micrococcus spp., Pasteurella spp., and Pseudomonas aeruginosa was low i.e., $5.55 \%, 5.55 \%$, and $1.85 \%$ respectively.

Mastitis is recognized as one of the very important diseases for dairy industry globally because of its economic significance. Practically, mastitis occurred in all domesticated species of animals and reported from all over the world (Halasa et al., 2007). The disease causes colossal losses in terms of reduced milk production, cost of treatment, veterinarian's fee, discarding of milk and many more (Yathiraj et al., 2007). Camel production contributes significantly to the national economy in Somalia as they form a significant proportion of livestock exports and it has the most camel population in the world (FAO, 2015). The Camel is a very important source of income in dairy industries in the climate of Benadir region of Somalia (Dubad et al., 2019), but their milking potential is affected by udder infections. The status of the disease remains largely unknown in this region, and yet there is no much researches has done toward such diseases. The prevalence of camel mastitis as discovered during this study is considered very low especially when compared to the report of Bekele and Molla (2001). Environmental factor as well as the handling practice of the owner might be a reason in variation of the prevalence of camel mastitis. Comparable result (15.8\%) is also reported by Abdurahman and Bornstein (1991) in Jijiga and higher rate of CMT result 47.3\% in Afar (Bekele and Molla, 2001). Tick burden, together with the thorny plant of desert and ant suckling material, seems to be a risk factor to the occurrence of mastitis in camels in the study area. Tick infestation can cause teat and skin lesions. This is one of the factors that predispose camels to mastitis since lesions caused by ticks facilitate bacterial entry and cause permanent tissue damage and influenced by poor hygiene of udder (Megersa, 2010). The definition related to the low prevalence of this study is the hygienic of milking ways and the good sanitized situation of the milking zone. It was also observed during this study that the prevalence of clinical mastitis was greater than subclinical mastitis. 
Table 1: The prevalence of clinical and subclinical mastitis based on animals and quarters on CMT and grown culture.

\begin{tabular}{|c|c|c|c|c|c|c|}
\hline \multirow[t]{2}{*}{ Types of infection } & \multirow{2}{*}{$\begin{array}{l}\text { No. of examined } \\
\text { camels }\end{array}$} & \multirow{2}{*}{$\begin{array}{l}\text { No. of examined } \\
\text { quarters }\end{array}$} & \multicolumn{2}{|c|}{ No. showing mastitis } & \multicolumn{2}{|c|}{ Prevalence rate on } \\
\hline & & & Animals & Quarters & Animal basis & Quarter basis \\
\hline Clinical & 79 & 320 & 18 & 30 & $22.78 \%$ & $9.37 \%$ \\
\hline Subclinical & 71 & 260 & 7 & 16 & $9.85 \%$ & $6.15 \%$ \\
\hline Total & 150 & 580 & 25 & 46 & $16.66 \%$ & $7.93 \%$ \\
\hline
\end{tabular}

Table 2: Spreading of clinical and subclinical infections in camels according to the quarter of position involved.

$\begin{array}{llllll}\text { Types of infection } & \text { No. of infected quarters } & \text { Left behind } & \text { Left front } & \text { Right behind } & \text { Right front } \\ \text { Clinical } & 30 & 10(33.33 \%) & 3(10.00 \%) & 11(36.66 \%) & 6(20.00 \%) \\ \text { Subclinical } & 16 & 3(18.75 \%) & 2(12.5 \%) & 7(43.75 \%) & 4(25.00 \%) \\ \text { Total } & 46 & 12(26.08 \%) & 3(6.52 \%) & 21(45.65 \%) & 10(21.73 \%)\end{array}$

Absolute values refer to total number of infection and values in parenthesis refer to the percentage of infection within the category.

Table 3: Comparative occurrence of different category of clinical and subclinical pathogens of mastitis infection.

\begin{tabular}{llll} 
Type of infection & Clinical & Subclinical & Total \\
\hline No. of quarters exanimated & 30 & 260 & 290 \\
No. of infected quarters & 23 & 15 & 38 \\
No. of mixed infection & 3 & 13 & 16 \\
Total isolations & 26 & 28 & 54 \\
Staphylococcus spp. & $12(46.15 \%)$ & $9(64.28 \%)$ & $21(38.88 \%)$ \\
Streptococcus spp. & $6(23.07 \%)$ & $4(14.28 \%)$ & $10(18.51 \%)$ \\
Corynebacterium spp. & $4(15.38 \%)$ & $4(14.28 \%)$ & $8(14.81 \%)$ \\
Enterobacterium spp. & $2(7.60 \%)$ & $6(21.42 \%)$ & $8(14.81 \%)$ \\
Micrococcus spp. & $1(3.84 \%)$ & $2(7.14 \%)$ & $3(5.55 \%)$ \\
Pasteurella spp. & $1(3.84 \%)$ & $2(7.14 \%)$ & $3(5.55 \%)$ \\
Pseudomonas aeruginosa & $0(0.00 \%)$ & $1(3.57 \%)$ & $1(1.85 \%)$
\end{tabular}

Absolute values refer to total number of pathogens and values in parenthesis refer to the percentage of pathogens within the category.

The majority of the clinical cases in this study were sub-acute infections, with signs of swelling of the udder and teats, heat, irregular milk discharge, congestion of mammary gland and painful condition. It was further observed that hind quarters were affected with clinical and subclinical infections more frequently than the fore-quarters. A higher risk of infections in hind quarters compared to the front ones which could be due to the unfavorable hygienic condition; greater exposure to dung and urine. As well as a result of the smaller size of the hind teats through a corresponding smaller teat canal, the defense prospective in the behind quarter could be reduced. However, (Saleh and Faye, 2011) found that subclinical mastitis was higher in forequarters than hind quarters. Bacteriologically, the present study reveals that gram-positive bacteria was the major causal agent of both clinical and subclinical mastitis in camel which is also supported by the study of Abdul et al. (2006); Regassa et al. (2013). A higher proportion of Staphylococcus spp. among gram-positive bacteria found in the study is also similar to the result of Woubit et al. (2001).

\section{Conclusions and Recommendations}

The current cross-sectional study revealed a low prevalence of mastitis in camel herds in Deyniile district of Benadir Region, Somalia but the segregation of pathogenic bacteria from the camel milk samples recommends the need for firm hygienic processes for the period of the production and conducting of camel milk to mitigate the risks of community/public health. There is a need to increase control measures of diseases through vaccination, educating nomadic pastoralism to minimize the adverse effect of mastitis on their daily life. 
The authors would like to appreciate Kasmo University, Mogadishu, Somalia for their overall guidance during the research activity. For providing the necessary facilities and support throughout the investigation.

\section{Author's Contribution}

MIM and OSLJ collected samples and performed laboratory testing. YAM performed statistical analysis. AIM and PM prepare the manuscript. PM finalize the manuscript, provide critical comments and corresponding the study. All authors read the manuscript and agree to be responsible for any aspect of the manuscript.

\section{Conflict of interest}

The authors have declared no conflict of interest.

\section{References}

Abdel, E.G.A., Hildebrandt, G., Kleer, J.N., Molla, B., Kyule, M.N. and Baumann, M.P., 2006. Comparison of California Mastitis Test (CMT), Somatic Cell Counts (SCC) and bacteriological examinations for detection of camel (Camelus dromedarius) mastitis in Ethiopia. Berl. Munch. Tierarztl. Wochenschr., 119(1-2): 45-49.

Abdurahman, O.S. and Bornstein, S., 1991. Diseases of camels (Camelus dromedarius) in Somalia and prospects for better health. Nomadic Peoples. 29: 104-112.

Ali, A., Baby, B. and Vijayan, R., 2019. From desert to medicine: a review of camel genomics and therapeutic products. Front. Genet., 10: 17. https://doi.org/10.3389/fgene.2019.00017

Bekele, T. and Molla, B., 2001. Mastitis in lactating camels (Camelus dromedarius) in Afar Region, north-eastern Ethiopia. Berl. Munch. Tierarztl. Wochenschr., 114(5-6): 169-172.

Dubad, A.B., Mahmud, M.S. and Hasan, H.M., 2019. Prevalence of mastitis in camel, cattle and goats at Benadir Region in Somalia. J. Vet. Sci. Technol., 10(5): 1000587.

FAO, 2015. Somalia exports 5.3 million animals, 6\% growth in 2015. Available at: http://www. fao.org/emergencies/fao-in-action/stories/ stories-detail/en/c/410993/ (accessed 14 April
FAO, 2020. Food and agricultural organization: Gateway to dairy production and products. Available at: http://www.fao.org/dairyproduction-products/production/dairyanimals/camels/en/\#: : text=Events,Camels, the $\% 20$ camels\%20of\%20the $\% 20$ mountains

Farah, K.O., Nyariki, D.M., Ngugi, R.K., Noor, I.M. and Guliye, A.Y., 2004. The Somali and the camel: Ecology, management and economics. Anthropologist. 6(1): 45-55. https://doi.org/10.1080/09720073.2004.11890 828

Halasa, T., Huijps, K., Østerås, O. and Hogeveen, H., 2007. Economic effects of bovine mastitis and mastitis management: A review. Vet. Q. 29(1): 18-31. https://doi.org/10.1080/0165217 6.2007 .9695224

Hegde, R., Isloor, S., Prabhu, K.N., Shome, B.R., Rathnamma, D., Suryanarayana, V.V.S., Yatiraj, S., Prasad, C.R., Krishnaveni, N., Sundareshan, S. and Akhila, D.S., 2013. Incidence of subclinical mastitis and prevalence of major mastitis pathogens in organized farms and unorganized sectors. Indian J. Microbiol., 53(3): 315-320. https://doi.org/10.1007/s12088-0120336-1

Hoque, M.N., Das, Z.C., Talukder, A.K., Alam, M.S. and Rahman, A.N.M.A., 2015. Different screening tests and milk somatic cell count for the prevalence of subclinical bovine mastitis in Bangladesh. Trop. Anim. Health Prod., 47(1): 79-86. https://doi.org/10.1007/s11250-0140688-0

Köhler-Rollefson, I., Mundy, P. and Mathias, E., 2001. A field manual of camel diseases. In: Traditional and modern health care for the dromedary. ITDG publishing. https://doi. org/10.3362/9781780441153

Megersa, B., 2010. An epidemiological study of major camel diseases in the Borana lowland, Southern Ethiopia. Oslo: Drylands Coordination Group. Report no. 58, pp. 32-33.

Mohamed, H., 2016. Somali camel traders pay the price of war in Yemen. Available at: https:// www.aljazeera.com/indepth/features/2016/04/ somali-camel-traders-pay-price-warsyria-160411092956190.html (accessed 22 June 2016).

Mpatswenumugabo,J.P., Bebora, L.C., Gitao, G.C., 
Mobegi, V.A., Iraguha, B., Kamana, O. and Shumbusho, B., 2017. Prevalence of subclinical mastitis and distribution of pathogens in dairy farms of Rubavu and Nyabihu districts, Rwanda. J. Vet. Med., Article ID 8456713. https://doi.org/10.1155/2017/8456713

Nur, A.H., 2006. Report on AnGR for Somaliland and Somalia, FAO. Available at: https://www.google.com/l? sa=tandrct=j and $q=$ ande $\operatorname{src}=$ sand source $=$ web and $c d=$ and cad $=$ rjaanduact $=8$ andved $=2$ ahUKEwjG65 HThs3qAhWHc30KHauVBBQQFjABe gQICBADandurl=http $\% 3 \mathrm{~A} \% 2 \mathrm{~F} \% 2 \mathrm{Fwww}-$ 2Fannexes\%2FCountryReports\%2FSomalia. ndusg=AOvVaw0S6mF5yfH4rQ9jPqeeW4fP

Obied, A.I., Bagadi, H.O. and Mukhtar, M.M., 1996. Mastitis in Camelus dromedarius and the somatic cell content of camels' milk. Res. Vet. Sci., 61(1): 55-58. https://doi.org/10.1016/ S0034-5288(96)90111-3

Quinn, P.J., Carter, M.E., Markey, B.K. and Carter, G.R., 1999. Clinical veterinary microbiology. Wolfe, Baltimore. pp. 327-344.

Regassa, A., Golicha, G., Tesfaye, D., Abunna, F. and Megersa, B., 2013. Prevalence, risk factors, and major bacterial causes of camel mastitis in Borana Zone, Oromia Regional State, Ethiopia. Trop. Anim. Health Prod., 45(7): 1589-1595. https://doi.org/10.1007/s11250-
013-0403-6

Saleh, S.K. and Faye, B., 2011. Detection of subclinical mastitis in dromedary camels (Camelus dromedaries) using somatic cell counts, californiamastitis test and udder pathogen. Emirates J. Food Agric., 2011: 4858. https://doi.org/10.9755/ejfa.v23i1.5312

Sharma, N., Pandey, V. and Sudhan, N.A., 2010. Comparison of some indirect screening tests for detection of subclinical mastitis in dairy cows. Bulg. J. Vet. Med., 13(2): 98-103.

Somalia Economy, 2020. Economy overview. Available at: https://theodora.com/wfbcurrent/ somalia/somalia_economy.html (accessed 27 Jan 2020).

Thrusfield, M., 2005. Survey. In: Veterinary Epidemiology. $3^{\text {rd }}$ edn. Black Well Science Ltd., London. pp. 228-246.

Woubit, S., Bayleyegn, M., Bonnet, P. and JeanBaptiste, S., 2001. Camel (Camelus dromedarius) mastitis in Borena, lowland pastoral area, southwestern Ethiopia. Revue d'élevage et de médecine vétérinaire des pays tropicaux., 54(3-4): 207-2012. https://doi.org/10.19182/ remvt. 9774

Yathiraj, S., Bhat, M.N., Deepti, B.R., Upendra, H.U. and Murlidhara, A., 2007. Pattern of bacterial isolates from mastitis cases in cows. Thesis, ISVM, Uttarakhand, India. 